\title{
Bioactive fractions from cantabrian anchovy (Engraulis encrarischolus) viscera
}

\author{
Armando BURGOS-HERNÁNDEZ ${ }^{1,2 \varsigma *}$, Ema-Carina ROSAS-BURGOS ${ }^{1,2}$, Marina MARTÍNEZ1, \\ Paloma-Nallely NUNCIO-JAUREGUI ${ }^{1}$, Frutos MARHUENDA ${ }^{3}$, Miroslava KAČÁNIOVÁ ${ }^{4}$, Jana PETROVÁ ${ }^{4}$, \\ Angel-Antonio CARBONELL-BARRACHINA ${ }^{2 \varsigma}$
}

\begin{abstract}
The potential of cantabrian anchovy (Engraulis encrarischolus) viscera as a source of bioactive compounds is of interest for both, pharmaceutical and food industries. Cantabrian anchovy guts and heads were freeze-dried, extracted with methanol and subjected to fractionation by solvent partitioning using hexane, ethyl acetate, and butanol. Fractions were tested for antimutagenic, antioxidant, antifungal, and antibacterial activity using the Ames test; DPPH, ABTS, and FRAP assays; the radial grown inhibition assay; and the microbroth dilution method, respectively. Five fractions were obtained from the anchovy gut methanolic extract, in addition to the hexane- (HF), ethyl acetate- (EAF), and butanol-soluble (BF) fractions, an aqueous-soluble fraction (ALF) and precipitated crystals (ACF) in this were also obtained. HF and EAF resulted to be antimutagenic, HF and ALF showed antifungal activity, BF and ACF showed the highest antioxidant potential, and HF and BF were antibacterial against several strains. Anchovy gut, which to the present study had not been reported for any bioactivity, has antimutagenic, antifungal, antioxidant, and antibacterial compounds, which need to be isolated for full characterization and study.
\end{abstract}

Keywords: antimutagenicity; antibiotic; antioxidant; fungistatic; anchovy gut.

Practical Application: Engraulis encrarischolus fractions might be used by both, biomedical and food preservation industries.

\section{Introduction}

Fisheries are generally industries that generate high amounts of wastes (skin, viscera, heads, bones, contaminated water, etc.). When not properly disposed, these kinds of wastes may have great impacts on the environment. By means of food technology, production of fish flour, protein hydrolyzates, enzyme concentrates, chitosan elaboration, etc., have constituted strategies for the use of these wastes, reducing their negative impacts on diverse ecosystems and, at the same time, providing them of a added-value to fisheries by-products. However, another alternative for the utilization of fisheries wastes is the search and isolation of bioactive or functional compounds.

Marine animals and plants, inhabiting a wide range of ecosystems some of them still unexplored, synthetize a number of compounds that have been found to have biological activities that are of great interest for industries such as food processing and biomedicine, among other (Suleria et al., 2016; Pereira et al., 2016; Zhang et al., 2016). Much of the research in this area has been focused on marine lipidic compounds found in seafood such as unsaturated fatty acids $\omega-3$ and $\omega-6$, to which prevention of chronico-degenerative illnesses have been attributed (Burgos-Hernández et al., 2001; Farzaneh-Far et al., 2010; Shahidi \& Miraliakbari, 2004; Ewaschuk et al., 2012; Chen et al., 2015; Darghosian et al., 2015; Leslie et al., 2015; Eide et al., 2016). However, little attention has been given to the chemical composition of seafood wastes (skin, viscera, and fish heads) as a source of biologically active molecules.

Based on the above, the aim of the present study was to detect and initiate the isolation of biologically active compounds from cantabrian anchovy (Engraulis encrarischolus) viscera that might be of potential interest for the biomedical and food processing industries.

\section{Materials and methods}

\subsection{Testing species}

Anchovy (Engraulis encrarischolus), captured in the Cantabrian Sea, was gutted and head and viscera were vacuum-packed, frozen, and transported to the Departamento de Tecnología Agroalimentaria, Universidad Miguel Hernández at Orihuela, Spain, where they were stored at $-20^{\circ} \mathrm{C}$ until used.

${ }^{1}$ Departamento de Tecnología Agroalimentaria, Universidad Miguel Hernández de Elche, Orihuela, Alicante, España

${ }^{2}$ Departamento de Investigación y Posgrado en Alimentos, Universidad de Sonora, Hermosillo, Sonora, México

${ }^{3}$ Departamento de Agroquímica, Bioquímica, Universidad de Alicante, Campus San Vicente del Raspeig, Alicante, España

${ }^{4}$ Department of Microbiology, Faculty of Biotechnology and Food Sciences, Slovak University of Agriculture in Nitra, Nitra, Slovak Republic

${ }^{5}$ These authors contributed equally to the present research work.

*Corresponding author: aburgos@guayacan.uson.mx 


\subsection{Fractionation of anchovy viscera}

\section{Methanolic extract}

Anchovy viscera were defrost, homogenized with a food processor, and lyophilized. Lyophilized anchovy viscera was combined with 6 parts (w/v) of methanol and agitated with a magnetic stirrer during $1 \mathrm{~h}$. The resulting mixture was filtered through a Whatman No. 1 filter paper and the methanol was evaporated using a rotaevaporator under negative pressure. The methanolic extract (ME) was stored at $-20^{\circ} \mathrm{C}$ until further fractionation.

\section{Methanolic extract fractionation}

In order to separate bioactive compounds, a serial solvent-partitioning procedure was carried out using hexane, ethyl acetate, and butanol. In a $1000 \mathrm{~mL}$ beaker the ME was combined with $300 \mathrm{~mL}$ of each, ultra-pure water and hexane, and this mixture was agitated with a magnetic stirrer for $1 \mathrm{~h}$. The resulting mixture was transferred into a $1000 \mathrm{~mL}$ separation funnel and the immiscible phases were allowed to separate for $24 \mathrm{~h}$. The aqueous phase was recovered in a graduated tube and placed in a beaker for further fractionation. The hexane phase was recovered in a distillation flask and the hexane was separated using a rotoevaporator under negative pressure in order to obtain the hexane-soluble fraction (HF).

The aqueous phase was combined with an identical volume of ethyl acetate and the procedure previously described for hexane was repeated in order to obtain the ethyl acetate soluble fraction (EAF). This same procedure was carried out with butanol in order to obtain the butanol-soluble fraction (BF). Finally, the aqueous phase resulting from this last step was evaporated stirring the solution under a fumes-extraction hood at $40{ }^{\circ} \mathrm{C}$ and the resulting dried materials were considered the aqueous fraction (AF).

\subsection{Antimutagenic activity}

\section{Bacterial cultures}

Salmonella typhimurium TA98 and TA100 tester strains were used. Fresh overnight tester axenic cultures were stored at $-80^{\circ} \mathrm{C}$ and routinely checked to confirm genetic characteristics using the procedure described by Maron \& Ames (1983).

\section{Antimutagenicity test}

The Ames test was used to test the antimutagenic activity of anchovy viscera fractions. Fractions were reconstituted with dimethyl sulfoxide (DMSO) to a final concentration of $10 \mathrm{mg} / \mathrm{mL}$, serially diluted $(1: 10 \mathrm{v} / \mathrm{v})$ also with DMSO and spiked with pure aflatoxin $\mathrm{AFB}_{1}\left(\mathrm{AFB}_{1}\right)$ (Sigma-Aldrich, St. Louis, MO, U.S.) to a final concentration of $500 \mathrm{ng}$ of $\mathrm{AFB}_{1} / 100 \mu \mathrm{L}$ of diluted extract. Metabolic activation system S9 mix (Aroclor 1254-induced, Sprague-Dawley male rat liver in $0.154 \mathrm{M} \mathrm{KCl}$ solution, Molecular Toxicology, Inc.; Annapolis, MD, U.S.) was used to bioactivate $\mathrm{AFB}_{1}$. Residual mutagenicity of $\mathrm{AFB}_{1}$ was assayed using the standard plate incorporation procedure described by Maron \& Ames (1983). Different $\mathrm{AFB}_{1}$ concentrations, including $500 \mathrm{ng} \mathrm{AFB}_{1} / 100 \mu \mathrm{L}$, were used as controls for both tester strains. All assays were performed in triplicate.

\subsection{Antioxidant activity}

DPPH, ABTS, and FRAP assays

The free radical-scavenging activity, exerted by the fractions obtained from anchovy viscera, was evaluated using the DPPH, ABTS, and FRAP methods. DPPH method, based on the DPPH (2,2-diphenyl-1-picrylhydrazyl) radical and reported by Brand-Williams et al. (1995), was carried out combining $10 \mu \mathrm{L}$ of each fraction with $40 \mu \mathrm{L}$ methanol, and $950 \mu \mathrm{L} \mathrm{DPPH}$ radical solution. This mixture was agitated and placed in the dark for $10 \mathrm{~min}$. The absorbance at $515 \mathrm{~nm}$ was measured in a UV-Vis Uvikon XS spectrophotometer (Bio-Tek Instruments, Saint Quentin Yvelines, France).

ABTS [2,2-azinobis-(3-ethylbenzotiazoline-6-sulfonic acid)] radical based- and $\mathrm{Fe}^{+3}$ reducing antioxidant power (FRAP) methods, were carried out according to Re et al. (1999) and Benzie \& Strain (1996), respectively. Briefly, $10 \mu \mathrm{L}$ of sample (anchovy fractions) were combined with $900 \mu \mathrm{L}$ of either an ABTS radical or FRAP reagent solution. The absorbance (at 734 and $593 \mathrm{~nm}$ for ABTS and FRAP, respectively) was measured after $10 \mathrm{~min}$ of reaction. In order to determine the antioxidant potential of the fractions, a 0.01-5.0 mM Trolox curve was prepared. All the analyses were carried out in triplicate with 2 independent repetitions.

\subsection{Antifungal activity}

\section{Spore suspension}

Sterile potato dextrose agar (PDA) contained in an Erlenmeyer flask was inoculated with an activated Alternaria alternata strain and incubated at darkness at $25{ }^{\circ} \mathrm{C}$ until sporulation. Upon sporulation, cultures were amended with $20 \mathrm{~mL}$ of a $0.1 \%$ Tween 80 solution whose spore concentration was determined with a Neubauer chamber. Resulted spore suspension was stored at $4{ }^{\circ} \mathrm{C}$ until used.

\section{Radial growth inhibition assay}

PDA Petri plates, amended with $2 \mathrm{mg} / \mathrm{mL}$ of anchovy gut fractions were inoculated with a $1 \times 10^{4}$ spore/mL suspension of Alternaria alternata culture, placing $30 \mu \mathrm{L}$ of this suspension in the center of the plate. Three controls were used in this assay, plates containing only PDA, other containing PDA + methanol, and another one containing PDA amended with $2 \mathrm{mg} / \mathrm{mL}$ of Armetil $^{\oplus}(8 \%$ metaloxyl $+64 \%$ mancozeb) as a positive control of fungal growth inhibition. Inoculated plates were incubated at $25^{\circ} \mathrm{C}$ in the dark and fungal radial growth was daily measured with a rule during a week. This assay was performed in triplicate.

\subsection{Antibacterial activity}

\section{Microbial test}

Six bacterial strains were tested in this research, including three Gram-negative bacteria (Escherichia coli CCM 3988, Shigella sonei CCM 1373 and Salmonella enterica subs. enterica CCM 3807), three Gram-positive bacteria (Bacillus subtilis sub. spizizenii CCM 1999, Enterococcus faecalis CCM 4224, Staphylococcus aureus subs. aureus CCM 2461). All tested strains 
were collected from the Czech Collection of Microorganisms. The bacterial suspensions were cultured in the nutrient broth (Imuna, Slovakia) at $37^{\circ} \mathrm{C}$ and the yeast suspension was cultured in the malt extract broth (Biomark, India) at $30^{\circ} \mathrm{C}$.

\section{Antimicrobial assay}

The minimum inhibitory concentration (MIC) is the lowest concentration of the sample that will inhibit the visible growth of microorganisms. Anchovy gut fractions dissolved in DMSO were prepared to a final concentration of $1024 \mu \mathrm{g} / \mathrm{mL}$ by dissolving stock solution with $102.4 \mathrm{mg} / 100 \mathrm{~mL}$. MICs were determined by the microbroth dilution method according to the Clinical and Laboratory Standards Institute recommendation 2009 in Mueller Hinton broth (Biolife, Italy) for bacteria. Briefly, the DMSO anchovy gut fractions solutions were prepared as serial two-fold dilutions, in order to obtain a final concentration ranging between $0.5-512 \mu \mathrm{g} / \mathrm{mL}$. Each well was then inoculated with microbial suspension at the final density of $0.5 \mathrm{McF}$ arland. After $24 \mathrm{~h}$ incubation of bacteria at $37^{\circ} \mathrm{C}$, the inhibition of microbial growth was evaluated by measuring the well absorbance at $450 \mathrm{~nm}$ in an absorbance microplate reader Biotek EL808with shaker (Biotek Instruments, USA). The 96 micro-well plates were measured before and after experiment. Differences between both measurements were evaluated as growth. Measurement error was established for 0.05 values from absorbance. Wells without anchovy gut fractions were used as positive controls of growth. Pure DMSO was used as negative control. This experiment was done in eight-replicates for a higher accuracy of the MICs of used anchovy gut fractions.

\subsection{Statistical analysis}

Data were analyzed using analysis of variance (ANOVA) with Tukey-Kramer test $(\mathrm{p}<0.05)$ with the aid of JMP statistical software (Visual statistical discovery, version software 5.01).

\section{Results}

\subsection{Antimutagenic activity}

The antimutagenic potential of fractions obtained from anchovy viscera was determined using Salmonella typhimurium TA100 tester strain and sodium azide as a control mutagen in order to test these fractions against a direct (does not requires bioactivation) mutagen. As shown in Table 1, all anchovy fractions were capable of inhibiting the mutagenicity induced by $1.5 \mu \mathrm{g}$ sodium azide / plate; however, only HF and EAF showed this antimutagenicity activity exhibiting a dose-response type of relationship. Similar results were observed when anchovy viscera fractions were tested against aflatoxin $\mathrm{B}_{1}\left(\mathrm{AFB}_{1}\right)$ (potent mutagen that requires bioactivation) and now using both, Salmonella typhimurium TA98 and 100 tester strains. In this assay (Table 2), HF and EAF could also partially inhibit the mutagenicity of $500 \mathrm{ng} \mathrm{AFB}_{1}$ /plate. Even though they did not show a clear dose-response type of relationship as against sodium azide, HF kept the number of revertants/plate at the spontaneous reversion level, suggesting the presences of strong antimutagenic compounds in this fraction.
Table 1. Anti-mutagenic potential of sodium azide ${ }^{\S}$-spiked anchovy viscera fractions (average ${ }^{\ddagger}$ Salmonella typhimurium TA100 revertants/plate).

\begin{tabular}{crccc}
\hline \multirow{2}{*}{ Extract $^{9}$} & \multicolumn{4}{c}{ Fraction concentration $^{\dagger}(\mathbf{m g} / \mathbf{p l a t e})$} \\
\cline { 2 - 5 } & $\mathbf{5 . 0}$ & $\mathbf{0 . 5}$ & $\mathbf{0 . 0 5}$ & $\mathbf{0 . 0 0 5}$ \\
\hline TA98 & & & & \\
HF & $140 \pm 20^{\mathrm{b}}$ & $180 \pm 11^{\mathrm{a}}$ & $212 \pm 10^{\mathrm{a}}$ & $225 \pm 35^{\mathrm{a}}$ \\
EAF & $83 \pm 77^{\mathrm{b}}$ & $118 \pm 33^{\mathrm{ab}}$ & $227 \pm 35^{\mathrm{a}}$ & -- \\
BF & $207 \pm 72^{\mathrm{b}}$ & $77 \pm 51^{\mathrm{b}}$ & $192 \pm 16^{\mathrm{ab}}$ & $212 \pm 34^{\mathrm{a}}$ \\
ALF & $474 \pm 32^{\mathrm{a}}$ & $201 \pm 1^{\mathrm{a}}$ & $159 \pm 15^{\mathrm{b}}$ & $163 \pm 32^{\mathrm{a}}$ \\
ACF & $161 \pm 20^{\mathrm{b}}$ & $172 \pm 34^{\mathrm{a}}$ & $149 \pm 10^{\mathrm{b}}$ & $176 \pm 16^{\mathrm{a}}$ \\
\hline
\end{tabular}

SSodium azide (used as positive control) tested at $1.5 \mu \mathrm{g} /$ plate induced $2613 \pm 1712$ revertants/plate. Spontaneous revertants were $146 \pm 20 .{ }^{*}$ Values are means of three replicates \pm standard deviation. ${ }^{\dagger}$ Extracts were diluted and spiked with enough sodium azide to yield $1.5 \mu \mathrm{g} /$ plate. ' $\mathrm{HF}=\mathrm{Hexanic}$ Fraction, EAF=Ethyl Acetate Fraction, $\mathrm{BF}=$ Butanolic Fraction, $\mathrm{ALF}=$ Aqueous Liquid Fraction, and $\mathrm{ACF}=$ Aqueous Crystallized Fraction. Different letter within a column means statistical differences $(p>0.05)$.

Table 2. Anti-mutagenic potential of aflatoxin $B_{1}\left(A_{1 F}\right)^{\varsigma_{-}}$-spiked anchovy viscera fractions (average* Salmonella typhimurium TA98 and TA100 revertants/plate).

\begin{tabular}{|c|c|c|c|c|}
\hline \multirow{2}{*}{ Extract ${ }^{9}$} & \multicolumn{4}{|c|}{ Fraction concentration $^{\dagger}(\mathrm{mg} /$ plate $)$} \\
\hline & 5.0 & 0.5 & 0.05 & 0.005 \\
\hline \multicolumn{5}{|l|}{ TA98 } \\
\hline $\mathrm{HF}$ & $43 \pm 8^{c}$ & $453 \pm 145^{\mathrm{a}}$ & $331 \pm 56^{\mathrm{a}}$ & $400 \pm 42^{\mathrm{a}}$ \\
\hline EAF & $200 \pm 33^{c}$ & $693 \pm 136^{\mathrm{a}}$ & $491 \pm 104^{\mathrm{a}}$ & $400 \pm 82^{a}$ \\
\hline $\mathrm{BF}$ & $1579 \pm 281^{\mathrm{a}}$ & $712 \pm 124^{\mathrm{a}}$ & $637 \pm 185^{\mathrm{a}}$ & $292 \pm 198^{\mathrm{a}}$ \\
\hline ALF & $903 \pm 152^{b}$ & $459 \pm 18^{\mathrm{a}}$ & $485 \pm 134^{\mathrm{a}}$ & $363 \pm 33^{\mathrm{a}}$ \\
\hline $\mathrm{ACF}$ & $1585 \pm 162^{a}$ & $677 \pm 46^{\mathrm{a}}$ & $357 \pm 33^{\mathrm{a}}$ & $555 \pm 68^{\mathrm{a}}$ \\
\hline \multicolumn{5}{|l|}{ TA100 } \\
\hline $\mathrm{HF}$ & $114 \pm 6^{\mathrm{d}}$ & $1387 \pm 66^{\mathrm{a}}$ & $1163 \pm 227^{\mathrm{a}}$ & $880 \pm 24^{\mathrm{ab}}$ \\
\hline EAF & $543 \pm 61^{c}$ & $1376 \pm 261^{a}$ & $792 \pm 44^{\mathrm{a}}$ & $1004 \pm 99^{\mathrm{a}}$ \\
\hline $\mathrm{BF}$ & $2206 \pm 109^{a}$ & $917 \pm 39^{\mathrm{a}}$ & $689 \pm 73^{\mathrm{a}}$ & $551 \pm 113^{b}$ \\
\hline ALF & $1676 \pm 303^{\mathrm{b}}$ & $1015 \pm 306^{\mathrm{a}}$ & $1019 \pm 148^{\mathrm{a}}$ & $1056 \pm 157^{\mathrm{a}}$ \\
\hline $\mathrm{ACF}$ & $597 \pm 66^{c}$ & $917 \pm 129^{\mathrm{a}}$ & $903 \pm 39^{\mathrm{a}}$ & $864 \pm 114^{\mathrm{ab}}$ \\
\hline \multicolumn{5}{|c|}{ 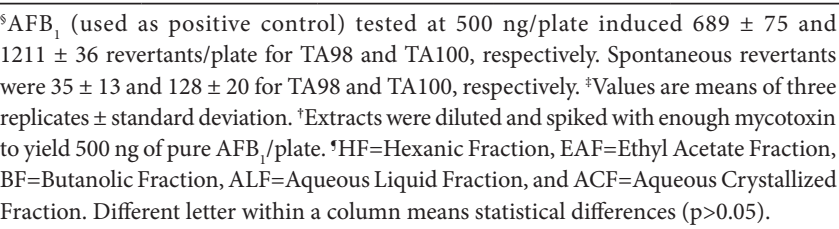 } \\
\hline
\end{tabular}

\subsection{Antioxidant activity}

Due to characteristics (yield and homogeneity), only HF, ALF, ACF, and BF were selected to antioxidant activity analyses. As shown in Table 3 , the antioxidant activity by all three methods used (DPPH, ABTS, and FRAP) ranged from 130-2328 mmol Trolox / Kg. The highest values were achieved by ACF for DPPH and ABTS, and by BF when the FRAP method was used. On the other hand, the lowest values were obtained using the FRAP method, almost by one order of magnitude and for all fractions tested, being the lowest value observed for ALF.

\subsection{Antifungal activity}

Figure 1 shows results obtained in the radial growth inhibition assay, where Alternaria alternata was grown in PDA medium amended with $2 \mathrm{mg} / \mathrm{mL}$ anchovy viscera fractions $\mathrm{HF}$ 
and ALF. Both fractions were capable of exerting inhibition of fungus radial growth, being up to $26 \%$ inhibition exerted by HF compared to controls. These results suggest the presence of antifungal compounds in these fractions, whose activity might be increased, as they could be further isolated.

\subsection{Antibacterial activity}

Hexanic (HF) and butanolic (BF) were tested for their antibacterial activity against three Gram (+) and three Gram (-) bacterial species that are of importance for the food industry. As shown in Table 4, values for the Minimal Inhibitory Concentration $50\left(\mathrm{MIC}_{50}\right)$ and $90\left(\mathrm{MIC}_{90}\right)$ were obtained for both anchovy viscera fractions against the six species tested. All these values ranged from $0.8-27.1 \mathrm{mg} / 100 \mathrm{~mL}$. Lowest values (indicating the highest antibacterial activity) were observed for HF against Enterococcus feacalis, Bacillus subtilis, and Staphylococcus aureus.

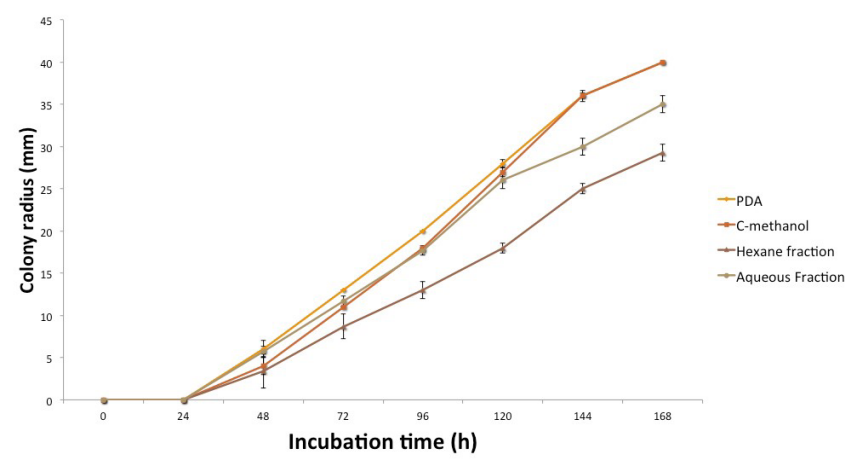

Figure 1. Radial growth of Alteraria alternata in the presence of anchovy viscera fractions. Potato Dextrose Agar (PDA) and PDA in the presence of methanol (C-methanol) were used as controls.

Table 3. Antioxidant activities of anchovy viscera fractions as assessed using the DPPH, ABTS, and FRAP methods.

\begin{tabular}{cccc}
\hline Fraction & $\begin{array}{c}\text { DPPH } \\
(\mathbf{m m o l} \text { Trolox/ Kg })\end{array}$ & $\begin{array}{c}\text { ABTS } \\
(\mathbf{m m o l} \text { Trolox/ Kg })\end{array}$ & $\begin{array}{c}\text { FRAP } \\
(\mathbf{m m o l} \text { Trolox/ Kg })\end{array}$ \\
\hline HF & $964.8^{\mathrm{a}} \pm 183.4$ & $1368.4 \pm 182.6$ & $183.0 \pm 56.14$ \\
$\mathrm{BF}$ & $1354.1 \pm 543.6$ & $2002.4 \pm 724.3$ & $457.6 \pm 410.3$ \\
$\mathrm{ACF}$ & $1522.1 \pm 330.5$ & $2328.2 \pm 513.6$ & $280.7 \pm 40.3$ \\
ALF & $820.3 \pm 438.4$ & $1246.2 \pm 691.0$ & $130.6 \pm 67.4$ \\
\hline
\end{tabular}

${ }^{a}$ Values are means from triplicates \pm SD.
It is important to mention that these values are comparable to those reported for commercial antibiotics, an issue that will be further discussed.

\section{Discussions}

The viscera from several marine species have been studied as a source of biologically active compounds. Antimutagenic compounds have been detected and isolated from several marine animals such as fish species (Burgos-Hernandez et al., 2002; Oh et al., 2008), crustaceans (Wilson-Sánchez et al., 2010; López-Saiz et al., 2014), and mollusks (Moreno-Félix et al., 2013; Cruz-Ramírez et al., 2015); however, studies reported the presence of antimutagenic compounds from seafood viscera were not found. In the present study, antimutagenic fractions obtained from cantabrian anchovy viscera are for the first time reported. Moreover, antimutagenic anchovy viscera fraction HF was found to be capable of inhibiting the mutagenicity of two types of potent mutagens (sodium azide and $\mathrm{AFB}_{1}$ ) down to the spontaneous reversion level, which suggest the presence of highly antimutagenic lipid soluble compounds that might be of great interest for the biomedical industry as a potential chemopreventive agents.

The antimutagenic activity detected in anchovy viscera is consistent with the high antioxidant activity determined in fractions obtained from this source. Even though, antioxidant activity has been reported in masou salmon (Oncorhynchus masou) (Oh et al., 2008), croaker (Otolithes ruber) (Nazeer et al., 2012), sardinelle (Sardinella aurita) (Bougatef et al., 2010), tilapia (Oreochromis niloticus) (Zhang et al., 2012); among other species, only one study was found where horse mackerel (Magalaspis cordyla) viscera extracts had antioxidant activity (Sampath-Kumar et al., 2011). In addition, is worth to mention that antioxidant activity values reached by BF (1354 mmol Trolox/Kg) and ACF (1522 mmol Trolox/Kgby the DPPH method, are similar to those reported in fruits such as apple $(1200-1600 \mathrm{mmol}$ Trolox/ Kg) and tangerine (1500-2000 mmol Trolox/Kg) (Pyo et al., 2014). All of the above suggest that cantabrian anchovy viscera is a source of both, hydrophobic and hydrophilic antioxidant compounds whose activity could be even much higher once they could be completely isolated; based on the that, these compounds have a high potential for being employed in both, food preservation industry as well as in the pharmaceutical area.

A low antifungal activity was found in fractions obtained from anchovy viscera, since only $26 \%$ of fungal growth inhibition

Table 4. Antibacterial activity of anchovy viscera fractions assessed on both, Gram (+) and Gram (-) species.

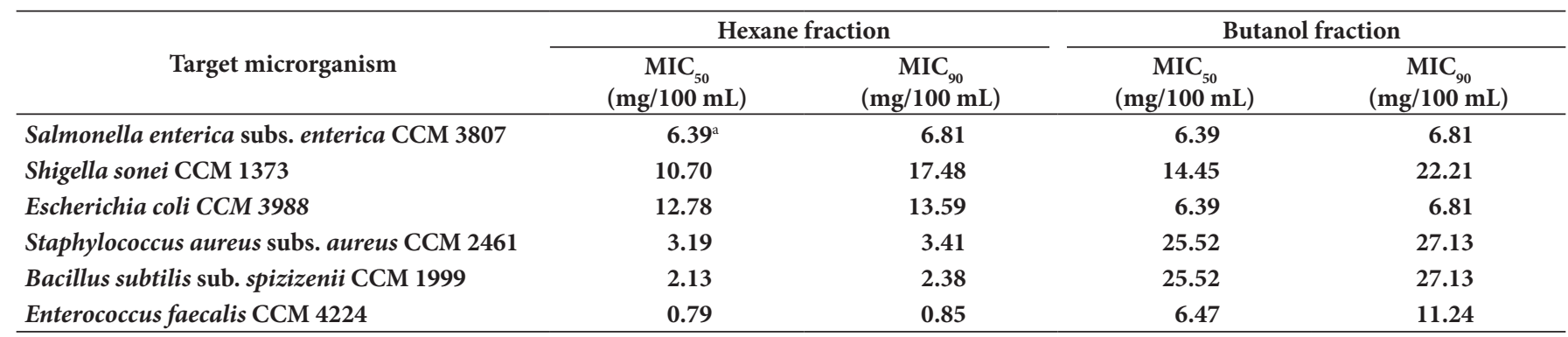

${ }^{a}$ Values are means from eight replicates. 
was achieved. Previous studies have reported antifungal peptides from sea lamprey (Petromyzon marinus) plasma (Rose \& Ourth, 2009) and protein compounds from mussel species Mytilus galloprovincialis (Sonthi et al., 2012) and Crenomytilus grayanus (Chikalovets et al., 2015). Based on this, the compounds responsible for the antifungal activity observed in the fractions from anchovy viscera, might be of protein or peptide nature, which possible were not appropriately extracted with the procedure used in the present study. Therefore, the use of an appropriate method to extract peptides from cantabrian anchovy viscera is recommended in order to more extensively investigate the antifungal potential of this source.

On the contrary to the low antifungal activity found in the anchovy fractions studied, a high antibacterial activity was observed in some of them. Antibacterial activity values observed ( $\mathrm{MIC}_{50}$ of $0.79 \mathrm{mg} \mathrm{HF} / 100 \mathrm{~mL}$ against Enterococcus faecalis CCM 4224) in these fractions are comparable to those that have been reported for commercial antibiotics such as vancomicin ( $\mathrm{MIC}_{50}$ of $0.2 \mathrm{mg} / 100 \mathrm{~mL}$ against Staphylococcus endophthalmitis) (Harper et al., 2007). However, the antibacterial activity (one order of magnitude higher than vancomicin $\mathrm{MIC}_{50}$ against Staphylococcus endophthalmitis) observed against the other species, as well as for the other bioactivities studied, could also increase with the isolation of the bioactive compounds. This suggests the presence of potent antimicrobial compounds that could be of great interest for the pharmaceutical industry.

\section{Conclusions}

Cantabrian anchovy waste such as viscera, contains antimutagenic, antioxidant, antifungal, and antibacterial compounds, which are mainly localized in the hexane-, butanol-, and methanol/water-soluble fractions. Even though it is recognized that the primary level of isolation impedes the bioactive compound to fully express their biological effects, the fact that this condition did not inhibit some antioxidant and antibacterial compounds to show very high levels of activity, suggests anchovy viscera as a promising source of bioactive compounds that are worthy of further research for biomedical, pharmaceutical, and food industries.

\section{Acknowledgements}

Authors wish to acknowledge CONACyT for the financial support granted to Burgos-Hernández, A., (234469) and Rosas-Burgos, E.C., (234051) to carry out a sabbatical-research staying at the Universidad Miguel Hernández de Elche at Orihuela, Alicante, Spain.

\section{References}

Benzie, I. F., \& Strain, J. J. (1996). The ferric reducing ability of plasma (FRAP) as a measure of "antioxidant power": the FRAP assay. Analytical Biochemistry, 239(1), 70-76. http://dx.doi.org/10.1006/ abio.1996.0292. PMid:8660627.

Bougatef, A., Nedjar-Arroume, N., Manni, L., Ravallec, R., Barkia, A., Guillochon, D., \& Nasri, M. (2010). Purification and identification of novel antioxidant peptides from enzymatic hydrolysates of sardinelle
(Sardinella aurita) by-products proteins. Food Chemistry, 118(3), 559-565. http://dx.doi.org/10.1016/j.foodchem.2009.05.021.

Brand-Williams, W., Cuvelier, M. E., \& Berset, C. (1995). Use of a free radical method to evaluate antioxidant activity. LWT - Food Science and Technology, 28(1), 25-30. http://dx.doi.org/10.1016/ S0023-6438(95)80008-5.

Burgos-Hernández, A., López-García, R., Njapau, H., \& Park, D. L. (2001). Partial chemical/structural elucidation of anti-mutagenic compounds from corn. Toxicology, 166(3), 161-170. http://dx.doi. org/10.1016/S0300-483X(01)00466-8. PMid:11543911.

Burgos-Hernandez, A., Peña-Sarmiento, M., \& Moreno-Ochoa, F. (2002). Mutagencity and antimutagencity studies of lipidic extracts from yellowtail fish (Seriola lalandi), lisa fish (Mugil cephalus) and cazón fish (Mustelus lunulatus). Food and Chemical Toxicology, 40(10), 1469-1474. http://dx.doi.org/10.1016/S0278-6915(02)000844. PMid:12387311.

Chen, G. C., Qin, L. Q., Lu, D. B., Han, T. M., Zheng, Y., Xu, G. Z., \& Wang, X. H. (2015). N-3 polyunsaturated fatty acids intake and risk of colorectal cancer: meta-analysis of prospective studies. Cancer Causes \& Control, 26(1), 133-141. http://dx.doi.org/10.1007/s10552014-0492-1. PMid:25416450.

Chikalovets, I. V., Chernikov, O. V., Pivkin, M. V., Molchanova, V. I., Litovchenko, A. P., Li, W., \& Lukyanov, P. A. (2015). A lectin with antifungal activity from the mussel Crenomytilus grayanus. Fish \& Shellfish Immunology, 42(2), 503-507. http://dx.doi.org/10.1016/j. fsi.2014.11.036. PMid:25482060.

Cruz-Ramírez, S. G., López-Saiz, C. M., Plascencia-Jatomea, M., MachiLara, L., Rocha-Alonzo, F., Márquez-Ríos, E., \& Burgos-Hernández, A. (2015). Isolation and identification of an antimutagenic phthalate derivative compound from octopus (Paraoctopus limaculatus). Tropical Journal of Pharmaceutical Research, 14(7), 1319-1326. http://dx.doi.org/10.4314/tjpr.v14i7.19.

Darghosian, L., Free, M., Li, J., Gebretsadik, T., Bian, A., Shintani, A., McBride, B. F., Solus, J., Milne, G., Crossley, G. H., Thompson, D., Vidaillet, H., Okafor, H., Darbar, D., Murray, K. T., \& Stein, C. M. (2015). Effect of omega-three polyunsaturated fatty acids on inflammation, oxidative stress, and recurrence of atrial fibrillation. The American Journal of Cardiology, 115(2), 196-201. http://dx.doi. org/10.1016/j.amjcard.2014.10.022. PMid:25465932.

Eide, I. A., Jenssen, T., Hartmann, A., Diep, L. M., Dahle, D. O., Reisæter, A. V., Bjerve, K. S., Christensen, J. H., Schmidt, E. B., \& Svensson, M. (2016). Plasma levels of marine n-3 polyunsaturated fatty acids and renal allograft survival. Nephrology, Dialysis, Transplantation, 31(1), 160-167. http://dx.doi.org/10.1093/ndt/gfv339. PMid:26410884.

Ewaschuk, J., Newell, M., \& Field, C. (2012). Docosahexanoic acid improves chemotherapy efficacy by inducing CD95 translocation to lipid rafts in ER(-) breast cancer cells. Lipids, 47(11), 1019-1030. http://dx.doi.org/10.1007/s11745-012-3717-7. PMid:23054549.

Farzaneh-Far, R., Lin, J., Epel, E., Harris, W., Blackburn, E., \& Whooley, M. (2010). Association of marine omega-3 fatty acid levels with telomeric aging in patients with coronary heart disease. Journal of the American Medical Association, 303(3), 250-257. http://dx.doi. org/10.1001/jama.2009.2008. PMid:20085953.

Harper, T., Miller, D., \& Flynn, H. W. Jr. (2007). In vitro efficacy and pharmacodynamics indices for antibiotics against coagulase-negative Staphylococcus endophthalmitis isolates. Ophthalmology, 114(5), 871875. http://dx.doi.org/10.1016/j.ophtha.2007.01.007. PMid:17383732.

Leslie, M. A., Cohen, D. J. A., Liddle, D. M., Robinson, L. E., \& Ma, D. W. L. (2015). A review of the effect of omega- 3 polyunsaturated fatty acids on blood triacylglycerol levels in normolipidemic and borderline 
hyperlipidemic individuals. Lipids in Health and Disease, 14(53), 1-29. http://dx.doi.org/10.1186/s12944-015-0049-7. PMid:26048287.

López-Saiz, C. M., Velázquez, C., Hernández, J., Cinco-Moroyoqui, F. J., Plascencia-Jatomea, M., Robles-Sánchez, M., Machi-Lara, L., \& Burgos-Hernández, A. (2014). Isolation and structural elucidation of antiproliferative compounds of lipidic fractions from white shrimp muscle (Litopenaeus vannamei). International Journal of Molecular Sciences, 15(12), 23555-23570. http://dx.doi.org/10.3390/ ijms151223555. PMid:25526568.

Maron, D. M., \& Ames, B. N. (1983). Revised methods for the Salmonella mutagenicity test. Mutation Research, 113(3-4), 173-215. http:// dx.doi.org/10.1016/0165-1161(83)90010-9. PMid:6341825.

Moreno-Félix, C., Wilson-Sánchez, G., Cruz-Ramírez, S. G., VelázquezContreras, C., Plascencia-Jatomea, M., Acosta, A., Machi-Lara, L., Aldana-Madrid, M. L., Ezquerra-Brauer, J. M., Rocha-Alonzo, F., \& Burgos-Hernandez, A. (2013). Bioactive lipidic extracts from octopus (Paraoctopus limaculatus): antimutagenicity and antiproliferative studies. Evidence-Based Complementary and Alternative Medicine, 2013, 1-12. http://dx.doi.org/10.1155/2013/273582. PMid:23401709.

Nazeer, R. A., Sampath-Kumar, N. S., \& Jai-Ganesh, R. (2012). In vitro and in vivo studies on the antioxidant activity of fish peptide isolated from the croaker (Otolithes ruber) muscle protein hydrolysate. Peptides, 35(2), 261-268. http://dx.doi.org/10.1016/j.peptides.2012.03.028. PMid:22504498.

Oh, H. T., Kim, S. H., Choi, H. J., Chung, M. J., \& Ham, S. S. (2008). Antioxidative and antimutagenic activities of $70 \%$ ethanol extract from masou salmon (Oncorhynchus masou). Toxicology In Vitro, 22(6), 1484-1488. http://dx.doi.org/10.1016/j.tiv.2008.05.002. PMid:18682318.

Pereira, R. B., Andrade, P. B., \& Valentao, P. (2016). Chemical diversity and biological properties of secondary metabolites from sea hares of Aplysia Genus. Marine Drugs, 14(2), 1-39. http://dx.doi.org/10.3390/ md14020039. PMid:26907303.

Pyo, Y. H., Jin, Y. J., \& Hwang, J. Y. (2014). Comparison of the effects of blending and juicing on the phytochemicals contents and antioxidant capacity of typical korean kernel fruit juices. Preventive Nutrition and Food Science, 19(2), 108-114. http://dx.doi.org/10.3746/ pnf.2014.19.2.108. PMid:25054109.
Re, R., Pellegrini, N., Proteggente, A., Pannala, A., Yang, M., \& RiceEvans, C. (1999). Antioxidant activity applying an improved ABTS radical cation decolorization assay. Free Radical Biology \& Medicine, 26(9-10), 231-237. PMid:10381194.

Rose, W. M., \& Ourth, D. D. (2009). Isolation of lysozyme and an antifungal peptide from sea lamprey (Petromyzon marinus) plasma. Veterinary Immunology and Immunopathology, 132(2-4), 264-269. http://dx.doi.org/10.1016/j.vetimm.2009.05.013. PMid:19552965.

Sampath-Kumar, N. S., Nazeer, R. A., \& Jaiganesh, R. (2011). Purification and biochemical characterization of antioxidant peptide from horse mackerel (Magalaspis cordyla) viscera protein. Peptides, 32(7), 1496-1501. http://dx.doi.org/10.1016/j.peptides.2011.05.020. PMid:21640151.

Shahidi, F., \& Miraliakbari, H. (2004). Omega-3 (n-3) fatty acids in health and disease: part 1 - cardiovascular disease and cancer. Journal of Medicinal Food, 7(4), 387-401. http://dx.doi.org/10.1089/ jmf.2004.7.387. PMid:15671680.

Sonthi, M., Cantet, F., Toubiana, M., Trapani, M. R., Parisi, M. G., Cammarata, M., \& Roch, P. (2012). Gene expression specificity of the mussel antifungal mytimycin (MytM). Fish \& Shellish Immunology, 32(1), 45-50. http://dx.doi.org/10.1016/j.fsi.2011.10.017. PMid:22037382.

Suleria, H. A. R., Gobe, G., Masci, P., \& Osborne, S. A. (2016). Marine bioactive compounds and health promoting perspectives; innovation pathways for drug discovery. Trends in Food Science \& Technology, 50, 44-55. http://dx.doi.org/10.1016/j.tifs.2016.01.019.

Wilson-Sánchez, G., Moreno-Félix, C., Velázquez, C., PlascenciaJatomea, M., Aldana-Madrid, M. L., Ezquerra-Brauer, J. M., RoblesZepeda, R., \& Burgos-Hernández, A. (2010). Antimutagenicity and antiproliferative studies of lipidic extracts from white shrimp (Litopenaeus vannamei). Marine Drugs, 8(11), 2795-2809. http:// dx.doi.org/10.3390/md8112795. PMid:21139845.

Zhang, G., Li, J., Zhu, T., Gu, Q., \& Li, D. (2016). Advanced tools in marine natural drug discovery. Current Opinion in Biotechnology, 42, 13-23. http://dx.doi.org/10.1016/j.copbio.2016.02.021. PMid:26954946.

Zhang, Y., Duan, X., \& Zhuang, Y. (2012). Purification and characterization of novel antioxidant peptides from enzymatic hydrolysates of tilapia (Oreochromis niloticus) skin gelatin. Peptides, 38(1), 13-21. http:// dx.doi.org/10.1016/j.peptides.2012.08.014. PMid:22955032. 